\title{
Gêneros e instrumentos da música popular urbana na "música de concerto" de Radamés Gnattali
}

\author{
Marcio Guedes Correa \\ Centro Universitário das Faculdades Metropolitanas Unidas \\ (FMU-FIAM-FAAM)
}

\begin{abstract}
Resumo
Radamés Gnattali (1906-1988) foi um compositor brasileiro que empreendeu uma trajetória musical pautada em grande diversidade de opções estéticas, gêneros e possibilidades de instrumentação e orquestração. Sua obra de concerto abarca diversos elementos oriundos da música popular urbana veiculada por rádios e gravações em discos de vinil. Entre esses elementos estão a escrita intrínseca ao jazz, as características musicais da seresta, do samba, da marcha carnavalesca e do choro e a utilização dos instrumentos consagrados por esses e outros gêneros brasileiros. Nesse artigo, descrevo parte da trajetória musical de Gnattali, tanto de sua formação musical quanto da vida profissional, buscando evidenciar as ocorrências que o levaram a compor música de concerto pautada pela música popular brasileira e pelo jazz. Ao final desse artigo, seleciono obras de seu catálogo em que o compositor insere instrumentos populares em sua obra de concerto. Penso que, ao abarcar esses elementos em sua música, Radamés Gnattali inaugura uma nova escrita na música de concerto brasileira.
\end{abstract}

Palavras-chave: Radamés Gnattali. Música popular urbana. Música de tradição oral. Música erudita. Música de concerto. Orquestração brasileira.

\section{Introdução}

Radamés Gnattali (1906-1988) é um compositor brasileiro que pode ser estudado a partir de dois campos da produção musical: a composição em música erudita e o arranjo na música popular. Conforme expresso por Barbosa e Devos (1984), Gnattali preferia usar o termo música de concerto ao invés de música erudita e, nesse sentido, a fala de Mario de Andrade parece-nos bastante adequada ao se reportar a designação música erudita:

Uma arte nacional já está feita na inconsciência do povo. O artista tem só que dar pros [sic] elementos já existentes uma transposição erudita que faça da música popular, música artística [...] não é possível mais imaginar um compositor que não seja um erudito da arte dele. (ANDRADE, 1962, p. 16,44).

No que diz respeito à música popular urbana, utilizamos a definição adotada por José Ramos Tinhorão: 
Por oposição à música folclórica (de autor desconhecido, transmitida oralmente de geração em geração), a música popular (composta por autores conhecidos e divulgadas por meios gráficos, como partituras, ou através da gravação de discos, fitas, filmes ou video-teipes [sic] uma criação contemporânea do aparecimento de cidades com um certo grau de diversificação social”. (TINHORÃO, s.d., p. 5).

Elizabeth Travassos (2007), de forma mais elucidativa, ao invés de utilizar o termo música folclórica, preferiu empregar o termo música de tradição oral, pois considerava que ele podia estar imbuído de significados qualitativos que acabavam por determinar que as músicas populares estavam em posição subalterna em relação à música da cultura europeia. Esta pesquisadora relata que a palavra música popular passou a ser utilizada para diferenciar o repertório da indústria fonográfica das músicas que permaneceram nas tradições orais, noção que está de acordo com o termo "música popular urbana" criado por Tinhorão.

Acolhendo as ideias adotados por esses autores, posso afirmar que a obra de concerto de Radamés Gnattali detém uma atitude rara na música erudita brasileira: um acentuado diálogo com a música popular e não só com o repertório costumeiramente classificado de folclórico. Os gêneros da música popular urbana e comercial, tais como, samba, choro, seresta, samba-canção, jazz etc., são constantemente empregados em suas composições, com recorrência notavelmente maior do que ocorre em outros compositores de sua época. Esse acentuado e singular diálogo não se dá apenas com a adoção de padrões estéticos dessa esfera de produção musical, mas também com o emprego constante dos instrumentos que estão vinculados aos gêneros da música popular. Guitarra elétrica, bateria, contrabaixo tocado com pizzicato ao modo jazzístico, cavaquinho, instrumentos de percussão populares, entre outros, são frequentemente utilizados por Gnattali em suas orquestrações. Seu extenso trabalho como arranjador de música popular em rádios e gravadoras o colocou em contato direto com os gêneros da música popular, seus músicos e seus instrumentos, tornando-o um profundo conhecedor desse campo musical. Gnattali acabou por abarcar todos esses conhecimentos também em sua música de concerto, sem se preocupar em estabelecer fronteiras muito claras entre a música erudita e a música popular.

Nesse artigo, busco tornar evidentes os momentos da trajetória de Radamés Gnattali que o colocaram em contato direto com a música popular comercial brasileira e com o jazz, principalmente os fatos que se referem à sua carreira de arranjador, e como os elementos e os instrumentos dos gêneros musicais dessas vertentes acabaram por incidir em parte relevante de sua obra de concerto.

\section{A trajetória musical híbrida de Radamés Gnattali}

Sabe-se que Radamés Gnattali é um músico de sólida formação musical devido aos seus estudos de piano, harmonia e análise, realizados em sua passagem pelo Conservatório de Música do Instituto de Belas Artes do Rio Grande do Sul. Quando Gnattali ainda era um 
jovem estudante de música, suas aspirações voltaram-se para seguir a carreira de concertista e professor de piano, objetivo característico da formação musical oferecida pelos conservatórios. Contudo, desde sua formação conservatorial, Radamés Gnattali já demonstrava grande interesse em compreender as estruturas das obras musicais que interpretava ao piano. Conforme expresso por Barbosa e Devos: "E daquelas partituras já aproveitava para ir colhendo os dados e os ensinamentos para seus primeiros ensaios na composição" (1984, p. 14).

Apesar de ser um estudante de piano e, portanto, aspirante a carreira de concertista e recitalista, Barbosa e Devos apontam para um certo desejo que Gnattali nutria de se tornar também um compositor. O jovem pianista, que antes do conservatório fora preparado musicalmente ao piano por sua mãe Adélia e ao violino por sua prima Olga Fossati, chegou a realizar, por volta dos seus dezoito anos de idade, recitais de sucesso no Rio de Janeiro e em outras cidades brasileiras, alguns deles organizados por seu professor da época do conservatório.

Guilherme Fontainha (professor de piano de Radamés Gnattali no Conservatório de Porto Alegre), usando de seu prestígio no Rio de Janeiro, conseguiu uma audição para Radamés no Instituto Nacional de Música, sendo marcada para o dia 31 de julho de 1924 a apresentação do pianista à sociedade carioca. Seria o primeiro recital Público. Depois de "impressionar magnificamente o auditório ao executar de forma brilhante a Sonata de Liszt na última audição do Conservatório de Porto Alegre", Radamés partiu para o Rio de Janeiro. (BARBOSA; DEVOS, 1984, p. 16).

Esse recital rendeu ao jovem pianista excelentes críticas da imprensa da época, o que resultou em convites para mais apresentações em território nacional. Mesmo com a promissora carreira de concertista em vista, agora já aprovada pelo público mais exigente e também mais cobiçado do Brasil na época, desde muito jovem, Radamés Gnattali iniciou seus trabalhos remunerados com música, o que nem sempre foi possível no campo dos recitais de piano. Precocemente, já trabalhava tocando violão e cavaquinho em serestas, blocos carnavalescos, regionais e bailes, e ao piano, trabalhava com a atividade que pode ser considerada o embrião da trilha musical para cinema; a animação de filmes mudos. Conforme relato de Barbosa e Devos: "Aos 16 anos, ganhando dez mil réis por dia, Radamés trabalhou no cine Colombo, no Bairro da Floresta, animando fitas de cinema mudo" (1984, p. 14).

No início de sua carreira e gozando da versatilidade que sua formação musical e suas funções como profissional vinham Ihe garantindo, ainda encontrou espaço para trabalhar com a música de concerto, não como concertista, mas como violista do quarteto Henrique Oswald:

Com esse quarteto fizemos muitos concertos em Porto Alegre, Caxias, São Leopoldo. Tocávamos Beethoven, Mendelsohn, e Dunah, entre outros. Era muito bom o quarteto. Ensaiávamos todo dia, na casa de um e de outro. Eu gostava daquilo... Este foi um período importante pra mim; o grupo de cordas é a base da 
sinfônica; quem sabe trabalhar com ele, sabe usar a orquestra. (GNATTALI apud BARBOSA; DEVOS, 1984, p. 23).

É possível constatar nestas palavras, que a composição musical, de alguma maneira, sempre esteve presente em seu modo de estudar música, como se já estivesse supondo que tal função poderia vir a ser o seu principal ofício no futuro. Já naquela época, Gnattali não estava preocupado apenas com nuances de interpretação das obras, como é comum aos intérpretes, mas também mergulhava em análises daquele repertório, recolhendo elementos que pudessem estruturar trabalhos composicionais posteriores.

Como pianista, por volta de 1929, chegou a acompanhar uma companhia de ópera no Teatro Lírico do Rio de Janeiro. Começou como violista da orquestra e depois passou a assistente de maestro já que sua leitura à primeira vista ao piano era notável. Nesta mesma época, de modo bem mais moderado, começou sua carreira de professor de piano, pois nunca teve muita paciência para ensinar.

Os acontecimentos, no entanto, pareceram favorecer bem mais a formação e a carreira do compositor do que a de pianista. Radamés Gnattali teve um pedido de bolsa de estudos de piano no exterior negado pelo governo do Rio Grande do Sul. Mais tarde, no primeiro mandato do então Presidente Getúlio Vargas, ele se preparou para um concurso de professor catedrático para atuar no Instituto Nacional de Música, concurso esse que nunca se realizou, pois foram nomeados alguns professores para ocupar as vagas disponíveis. Gnattali então se viu obrigado a continuar trabalhando com a música popular. Passou a compor obras de concerto em algum ponto indeterminado de sua carreira, e essa produção se intensifica, possivelmente como mais uma possibilidade de renda.

Não foram localizados dados ou fontes que pudessem determinar com exatidão quando se iniciaram os primeiros ensaios de composição de Radamés Gnattali, no entanto, Barbosa e Devos apontam a data de 1930 como de estreia do compositor frente ao público com a peça "Rapsódia Brasileira para Piano" (BARBOSA; DEVOS, 1984, p.28).

Em suas primeiras obras de concerto, Radamés Gnattali chegou a ser considerado um nacionalista:

A atuação de Radamés como compositor tomava proporções inesperadas. Há um ano da execução de sua primeira obra, a sala Beethoven apresentava a Noite Brasileira de Radamés Gnattali e Luiz Cosme. O aproveitamento de temas folclóricos e populares nas composições de Radamés já demonstrava a sua tendência nacionalista. "Radamés, como muitos belos espíritos da nova geração de músicos brasileiros - escreveu Ângelo Guido no Diário de Notícias -, aspira a fazer música nossa, em que sejam aproveitados os ritmos típicos, originalíssimos, de nossa música folclórica, que é aquela que fala à alma de nossa gente". (BARBOSA; DEVOS, 1984, p.29). 
Mais tarde, suas composições tendem muito mais ao alinhamento com a música popular urbana, do que com a música de tradição oral. O aproveitamento de temas folclóricos, uma das características do nacionalismo mencionada tanto por Barbosa e Devos quanto por Guido, articulista do Diário de Notícias, vai se rarefazendo no desenvolvimento do seu estilo de compositor e arranjador. Além disso, não existe registros de que Gnattali tenha desenvolvido alguma pesquisa etnomusicológica no intuito de recolher temas folclóricos para embasar suas composições. De acordo com Roland de Candé (1994), a pesquisa etnomusicológica é característica indissociável dos compositores nacionalistas de qualquer nação:

As escolas nacionais surgidas no século XIX ganham no século XX novo alento. Como mostra o musicólogo romeno Constantin Brailou, o mundo sonoro aberto por Debussy é mais favorável ao desabrochar das melodias populares do que à harmonia tonal e às formas clássicas. Além disso, o estudo folclórico se desenvolverá sob o impulso de Béla Bartók e Zoltan Kodály (1882 - 1967), que publicam em 1906 sua primeira coletânea de canções camponesas. Mais tarde, Bártok notará e gravará em rolos fonográficos cerca de dez mil melodias populares, húngaras, eslovacas, romenas, ucranianas, servo-croatas, búlgaras, turcas, árabes (no sul argelino), trabalho de uma amplitude e de uma qualidade científica sem precedentes. As correntes nacionais, ligadas outrora aos irredentismos do período após 1848, apoiam-se cada vez mais no conhecimento aprofundado de um autêntico patrimônio, cujas características distintivas são assimiladas por muitos compositores. (CANDÉ, 1994, v. II, p. 258).

A iniciativa da pesquisa etnomusicológica não é parte das práticas profissionais de Radamés Gnattali. Seus estudos de música popular recaem acentuadamente sobre o repertório da canção veiculada pelas rádios e gravadoras, sobre o choro e sobre o jazz. Esse alinhamento de Gnattali com a música popular urbana o afasta cada vez mais da linha estética dos compositores nacionalistas brasileiros:

O problema é que o nacionalismo musical modernista toma a autenticidade dessas manifestações (folclóricas rurais) como base de sua representação em detrimento das movimentações da vida popular urbana porque não pode suportar a incorporação desta última, que desorganizaria a visão centralizada homogênea e paternalista da cultura nacional. (SQUEFF; WISNIK, 1982, p. 133).

Parecia ser nítido para o nacionalismo desta época que a verdadeira essência da música brasileira residia realmente na música folclórica:

[...] a plataforma ideológica do nacionalismo musical consistia justamente na tentativa de estabelecer um cordão sanitário defensivo que separasse a boa música (resultante da aliança da tradição erudita nacionalista com o folclore) da música má (a popular urbana comercial e a erudita europeizante, quando esta quisesse passar por música brasileira, ou quando de vanguarda radical). (SQUEFF; WISNIK,1982, p. 134).

Squeff e Wisnik deixam claro que o nacionalismo no Brasil não aceitou a música popular urbana como parte de sua metodologia, pois essa, por estar em constante transformação - 
contrariamente à música de tradição oral - não era um exemplar da essência musical do brasileiro. Radamés Gnattali, por sua vez, sempre permitiu que houvesse uma aliança estética entre a música popular brasileira urbana, o jazz e a música de concerto em sua obra de concerto. A questão é que o elemento nacional da música de Gnattali não repousava, ou raramente repousa, na música de tradição oral, fato que provavelmente o distanciou dos meios musicais criados pelos compositores eruditos nacionalistas de sua época, resultando em uma certa ofuscação de sua obra e, consequentemente, de seu nome na história da música brasileira. O trabalho de arranjador deste compositor recebe muito mais espaço na memória nacional do que sua produção como compositor erudito, principalmente nos estudos sobre o rádio no Brasil, como por exemplo, no livro de Sérgio Cabral A MPB na era do Rádio (CABRAL, 1996).

Em 1964, já consagrado como arranjador e compositor por estar trabalhando e ganhando seu sustento escrevendo música, ele volta às salas de concerto como camerista, viajando para o exterior com o violoncelista lberê Gomes Grosso, para apresentar suas composições. Voltar por um período às salas de concerto é para Gnattali uma tomada de fôlego dentre todos os seus trabalhos de arranjador de música popular. É o próprio compositor gaúcho quem declara: "Amo a música popular, mas se pudesse trabalharia exclusivamente sobre a música erudita" (BARBOSA; DEVOS,1984, p. 63).

É relevante declarar que no início de sua carreira a música popular já estava estabelecida no Brasil, e as atividades práticas desenvolvidas nesse setor, garantiam aos músicos alguma remuneração, esse talvez foi o motivo mais relevante para que ele atuasse como um compositor híbrido.

Mais adiante, Gnattali também atuou no mercado de gravações de música popular, escrevendo arranjos orquestrais para os principais cantores da música popular brasileira, como Orlando Silva, entre outros, ou tocando piano, como fez mais tarde em gravações de Dorival Caymmi.

Apesar de ter nascido e atuado no Rio Grande do Sul, de ter trabalhado como músico em São Paulo, é no Rio de Janeiro que o músico viria a estabelecer residência e, antes disso, foi nesta mesma cidade que tomou contato com músicos populares cujas produções musicais teriam papel determinante em sua carreira de compositor e de arranjador. Entre esses músicos, Ernesto Nazareth merece destaque:

Ouvir Ernesto Nazareth do lado de fora do Cinema Odeon foi para Radamés, se não o ideal, o suficiente para perceber todas as nuances de interpretação daquele já consagrado pianista... O pianista Radamés dessa época, ao contrário de Nazareth, seguia o mesmo rumo dos concertistas, pela interpretação dos clássicos. (BARBOSA; DEVOS, 1984, p. 17). 
Pixinguinha foi outro músico popular com quem Gnattali conviveu no Rio de Janeiro e que foi fundamental para o desenvolvimento de sua obra. Gnatalli costumava dizer que apreciava muito o choro, mas "os bons mesmo são os do Pixinguinha" ${ }^{1}$. A aproximação com a música e os compositores da música popular urbana e o aprofundamento nesse repertório demonstram que Radamés Gnattali não parecia estar preocupado em se enquadrar como um compositor nacionalista, ao contrário, em sua fase madura de composição aparentava estar bem resolvido com relação à sua música, considerada por alguns, difícil de ser encaixada em qualquer padrão que a conduzisse a uma definição precisa. Aloísio Didier em seu livro Radamés Gnattali (1996) por diversas vezes deixa transparecer o quanto foi e é difícil enquadrar Gnattali em uma definição, seja como músico erudito, popular ou nacionalista. Para Didier, Radamés é o "músico total" por ter realizado com maestria todas as funções musicais às quais se submeteu e estas foram, bastante diversas.

Em 1930 ocorre um marco importante para a grande proximidade desse compositor com o repertório popular das rádios e gravadoras. Gnattali assume o cargo de regente e posteriormente de arranjador na Rádio Transmissora. A estabilidade financeira alcançada nesse emprego e a prática diária de escrita de arranjos orquestrais geraram as condições necessárias para o desabrochar definitivo de sua carreira de compositor.

É na Rádio Transmissora que Radamés Gnattali toma contato com a escrita orquestral do jazz, com a inclusão da Big Band na orquestra sinfônica, devido a visão comercial do diretor artístico desta instituição, Mr. Evans, que percebia que o disco internacional tomava conta do mercado brasileiro.

$\mathrm{Na}$ visão de Evans, os elaborados arranjos orquestrais do disco norte-americano eram o motivo de seu sucesso e por isso, desejou ter no Brasil o mesmo nível de elaboração musical. Contratou Radamés Gnattali como maestro e lhe pediu para organizar uma orquestra grande e completa. Gnattali incluiu nessa orquestra cinco saxofones e estabeleceu a utilização de quatro trompetes e quatro trombones - intrumentação característica das big bands. Conforme relatado por Lowell e Pullig (2003, p.25), a big band é um grupo instrumental composto por dois saxofones altos, dois saxofones tenores, um saxofone barítono, quatro trompetes, quatro trombones, guitarra elétrica, piano, contrabaixo e bateria.

No início foi contratada um arranjador paulista chamado Galvão, que havia estudado música nos Estados Unidos, e esse escreveu as primeiras partituras para a orquestra da Rádio Transmissora: "O Galvão fez os arranjos e eu gostei. Comecei a estudar aquelas partes e comecei a aprender" (GNATTALI apud BARBOSA E DEVOS, 1984, p. 35). A partir desse momento, Radamés passa a escrever para essa orquestra, utilizando as novas técnicas de orquestração herdadas do jazz. Algum tempo depois, Gnattali se estabelece

\footnotetext{
${ }^{1}$ Ver o vídeo Nosso Amigo Radamés Gnattali (Brasiliana Produções).
} 
profissionalmente nesta nova função - a de arranjador, surgida a partir da música popular urbana.

Até então esse profissional não existia na música de concerto, pois o compositor elaborava a partitura musical completa, com a parte de todos os instrumentos e é esse todo que se configurava como uma composição. O arranjo teve espaço na música erudita apenas nas transcrições e adaptações de obras para conjuntos instrumentais diferentes do original. A nova profissão é classificada por José Ramos Tinhorão como uma necessidade de mercado:

Com o aparecimento das gravações, primeiro em cilindros e logo em discos, a produção de música popular iria ter ampliadas tanto sua base artística quanto industrial: A primeira, através da profissionalização dos cantores (solistas ou dos coros), da participação mais ampla de instrumentistas (de orquestras, bandas e conjuntos em geral) e do surgimento de figuras novas (o maestro arranjador e o diretor artístico); a segunda através do aparecimento das fábricas que exigiam capital, técnica e matéria prima. (TINHORÃO, 1998, p. 247).

Gnattali tinha plena consciência da condição de sua profissão de arranjador, pois ele mesmo cita a necessidade, na época, de concorrer com o disco americano, que chegava com grande sucesso ao Brasil. Essa aproximação e gosto pelo gênero de música norte americana possivelmente contribuiu também, no campo de suas composições de concerto, para o afastamento de uma escrita nacionalista.

A inclusão de um contrabaixo acústico tocado em pizzicato ao modo jazzístico e da bateria ${ }^{2}$ também fizeram parte da orquestra destinada aos arranjos de música popular de Gnattali e os mesmos são utilizados também em sua obra autoral, principalmente no Sexteto Radamés Gnattali, que inclui, neste caso, a guitarra elétrica, instrumento também ligado às Jazz Bands. A guitarra elétrica ainda ganharia destaque como solista, ao lado do piano, em seu Concerto Carioca oㅜ 1, escrito entre 1949 e 1950 e gravado em 1960 pela gravadora Continental, com o compositor ao piano e José Menezes à guitarra elétrica. Este foi o primeiro concerto da história escrito para guitarra elétrica (CORREA, 2007).

Quando o maestro Radamés Gnattali assume definitivamente a função de arranjador, sente a necessidade de incluir na orquestra, além de instrumentos oriundos do jazz, instrumentos ligados à música popular brasileira, principalmente os de percussão. Era comum também em sua orquestra, seja nos arranjos ou nas composições, a utilização do cavaquinho e do acordeom, instrumentos estes ligados ao grupo regional, formação instrumental muito utilizada para se acompanhar cantores nas rádios e gravadoras.

\footnotetext{
2 No livro História Social da Música Popular Brasileira de José Ramos Tinhorão (1998), ele faz alusão à "bateria compacta" como uma das necessidades de adaptação da música popular brasileira às jazz bands, já que esse instrumento é decorrente das necessidades musicais do jazz.
} 
O agrupamento instrumental chamado grupo regional, antes foi designado "grupo de pau e corda, devido à junção da flauta de ébano com os instrumentos de corda. Ele recebe este nome pela associação de sua instrumentação com as músicas regionais, que também utilizavam cavaquinho, violões, percussão e instrumento solista. André Diniz esclarece que esse agrupamento instrumental foi amplamente utilizado na música comercial. Era a principal mão-de-obra dos programas de rádio, inclusive tapando os frequentes furos da programação (DINIZ, 2003, p. 32). Essa atitude marcou de maneira decisiva o seu estilo de composição na área da música de concerto.

Seria tarefa de grande valor realizar uma análise aprofundada do estilo de orquestração e composição de Radamés Gnattali, buscando colocar em relevo os elementos dos gêneros populares que estão fortemente presentes em suas composições, tendo como base as partituras de suas $274^{3}$ obras de concerto. No entanto, grande parte dessa obra permanece em manuscritos originais do compositor. Ainda há poucas partituras digitalizadas ou editadas. Embora existam em maior abundância, não há também um número muito grande de gravações das obras de Gnattali, mas é a partir delas, grande parte realizadas com o compositor ao piano ou regência, que é possível constatar a imensa presença dos elementos musicais dos gêneros populares veiculados pelas rádios e gravadoras.

O Concerto Carioca $\mathrm{n}^{01}$, por exemplo, foi profundamente analisado, a partir da cópia fac-similar de um manuscrito de Gnattali, com o objetivo de descortinar a presença acentuada dos elementos estruturais e dos instrumentos dos gêneros da música popular urbana na obra de concerto de Radamés Gnattali. Conforme expresso por Correa (2007), esse procedimento inaugura uma nova escrita na música erudita brasileira.

Tendo em vista a escassez de partituras disponíveis, das 274 obras de concerto de Gnattali, resta-nos, por hora, apresentar um recorte de seu catálogo que elenca obras em que ficam claros os empregos dos instrumentos vinculados à música popular. São 48 obras, escritas para orquestra sinfônica, orquestra de câmara, orquestra de cordas e grupos de câmara, nas quais são empregados instrumentos musicais peculiares dos gêneros populares. A partir da instrumentação utilizada nessa seleção, podemos perceber o forte vínculo de Radamés Gnattali com a música popular urbana.

\section{Catálogo de obras}

A lista de peças indicada a seguir consta no Catálogo Digital da Brasiliana Produções. O livro Radamés Gnattali, o eterno experimentador (BARBOSA; DEVOS, 1984) apresenta um catálogo de obras, porém, não traz detalhamentos a respeito da orquestração ou

\footnotetext{
${ }^{3}$ Ver o site www.radamesgnattali.com.br. Neste endereço foi publicado, em 2007, o catálogo digital realizado pela Brasiliana Produções. Em acesso realizado no dia 03/05/2019 constava mensagem de manutenção do site: "em breve, novo site do Catálogo Digital Radamés Gnattali".
} 
instrumentação empregada em cada uma delas. As autoras citam que determinada peça foi escrita para orquestra sinfônica, mas não minudenciam a instrumentação escolhida pelo compositor. Só é possível constatar alguma experimentação instrumental nesse catálogo quando ela está descrita no título da composição. Esses dois catálogos são, até o momento, as únicas fontes disponíveis com relação à catalogação completa das obras de Radamés Gnattali. Há um outro catálogo disponível no volume da coleção Compositores de América: Dados Biográficos y Catálogos de Sus Obras, Volume 16, que está incompleto, pois o livro foi publicado em 1970, data em que ainda restavam dezoito anos de vida ao compositor.

A lista em que Gnattali utilizou instrumentos musicais ligados à música popular foi por mim dividida em peças para orquestra sinfônica, orquestra de câmara, orquestra de cordas e música de câmara. Faço isso para demonstrar a grande presença de instrumentos oriundos da música popular na obra de concerto de Radamés Gnattali. Segue a lista, baseada no catálogo digital, de obras em cada um dos gêneros musicais abaixo descritos.

\subsection{Peças para Orquestra Sinfônica}

Brasiliana no 10 (1970). Escrita para grande orquestra (duas flautas, flautim, dois oboés, corno inglês, dois clarinetes, dois fagotes, quatro trompas, três trompetes, três trombones, tuba, tímpano, pratos, caixa, bombo e cordas completas) com inclusão de instrumentos ligados à música popular brasileira, tais como, triângulo - tocado ao modo popular, seguro pela mão esquerda do músico, sem estar preso ao suporte - gonguê, recoreco e caixeta, equivalente a uma caixa de madeira - nome dado no Brasil ao wood block (FRUNGILLO, 2003, P. 56).

Brasiliana no 3 (1971). Grande orquestra (duas flautas, flautim, dois oboés, corno inglês, dois clarinetes, clarinete baixo, dois fagotes, quatro trompas, três trompetes, três trombones, tímpano, pratos, caixa, bombo, piano e cordas completas) com triângulo, pandeiro sem couro, tarol e zabumba. O tarol é um tambor com duas peles e esteira na pele de resposta, tocado com baquetas de madeira e pendurado ao ombro do instrumentista. Espécie de caixa. (FRUNGILLO, 2003, P. 340).

Concerto Carioca no 1 (1950). Escrito para violão elétrico, piano, orquestra (duas flautas, flautim, oboé, corno inglês, trompa, quatro trompetes, quatro trombones, tuba, pratos, bombo, tímpano, primeiros violinos 1 e 2 , segundos violinos 1 e 2 , violas 1 e 2 , violoncelos 1 e 2 e contrabaixos), inclusão de dois saxofones altos, dois saxofones tenores e saxofone barítono nas madeiras, e percussão popular com instrumentos de escola de samba (seis tamborins, dois reco-recos, dois chocalhos, pandeiro e surdo). Com respeito ao violão elétrico, este instrumento utilizado neste concerto, na verdade, foi a guitarra elétrica. Em entrevista a mim concedida, o multi-instrumentista José Menezes revelou que usou uma guitarra elétrica da marca Gibson, modelo Les Paul, para realizar a gravação dessa obra. Segundo Menezes, 
à época da gravação do concerto, 1960, era comum chamar esse instrumento de violão elétrico aqui no Brasil, somente mais tarde ele passou a ser denominado guitarra (CORREA, 2007).

Concerto Carioca no 2 para piano, contrabaixo e bateria com orquestra (1964). Nesta obra, Radamés Gnattali destaca como solistas, o trio que nessa época já era bastante utilizado pelos músicos de jazz - piano, contrabaixo e bateria - acompanhados por uma orquestra formada por flauta, oboé, corno inglês, clarinete, fagote, trompa, três trompetes, três trombones, tímpano, pratos, caixa, bombo e cordas completas. Tal citação ao jazz limita-se à escolha dos instrumentos, já que a obra é bastante brasileira e possui três movimentos intitulados samba, samba-canção e choro.

Concerto Carioca no 3 para flauta, saxofone alto, violão, contrabaixo e bateria, com orquestra (1972-73). Nessa obra, o compositor utiliza flauta, saxofone alto, violão, contrabaixo (tocado ao modo jazzístico em pizzicato) e bateria como grupo instrumental principal, acompanhado por orquestra sinfônica (duas flautas, dois oboés, dois clarinetes, dois fagotes, quatro trompas, quatro trompetes, quatro trombones, tuba, tímpano, prato, caixa, bombo e cordas completas).

Concerto Carioca no 3 (1970) - Versão original para quinteto Radamés Gnattali e orquestra (mesma formação da versão de 1972-73), com segundo piano opcional (1970). O quinteto Radamés Gnattali era formado por piano, bateria, contrabaixo, guitarra elétrica e acordeom. Em alguns casos, o grupo era convertido em um sexteto com a inclusão do segundo piano, que era tocado por sua irmã Aída Gnattali.

Concerto no 2 para piano e orquestra (1934). Nesta obra o compositor escreve um concerto para piano e grande orquestra (duas flautas, flautim, dois oboés, corno inglês, dois clarinetes, clarinete baixo, dois fagotes, quatro trompas, dois trompetes, três trombones, tuba, triângulo, pratos, bombo, tímpano e cordas completas) e inclui a bateria na família da percussão.

Concerto no 3 (seresteiro) para Camerata Carioca, piano e orquestra (198?). Adaptação do Concerto Seresteiro para Piano e orquestra nํ 3, de 1961-62, com a inclusão do grupo Camerata Carioca, que em sua formação contava com dois violões, violão de sete cordas, bandolim, cavaquinho e pandeiro, uma das possíveis formações de um regional, sendo acompanhado pela orquestra (duas flautas, dois oboés, corno inglês, dois clarinetes, clarinete baixo, dois fagotes, quatro trompas, três trompetes, quatro trombones, tuba, tímpano, pratos, caixa, bombo e cordas completas).

Fantasia Brasileira no 1 para piano e orquestra (1936). Além do piano e grande orquestra (duas flautas, flautim, dois oboés, dois fagotes, dois clarinetes, clarinete baixo, quatro trompas, três trompetes, dois trombones, tuba, tímpano, pratos, bombo, e cordas completas) há a utilização da bateria, reco-reco e chocalho na percussão. 
Fantasia Brasileira no 1 para piano e orquestra, segunda versão (1936). Nesta versão, incluem-se dois saxofones altos, dois saxofones tenores, saxofone barítono, bateria e contrabaixo elétrico. Embora seja uma Fantasia Brasileira, Gnattali busca a sonoridade de uma big band junto à orquestra (duas flautas, três trompetes, quatro trombones, tímpano, vibrafone e cordas completas). Para sonoridades de música popular brasileira o compositor utiliza dois violões como instrumentos de acompanhamento.

Fantasia Brasileira no 3 para piano e orquestra (1953). Nessa peça, além do piano e grande orquestra (flauta, flautim, oboé, clarinete, clarinete baixo, trompa, três trompetes, três trombones, tuba e cordas completas) há instrumentos ligados à big band, que são dois saxofones altos, dois saxofones tenores, saxofone barítono e bateria, além do acordeom que no Brasil era um instrumento muito comum aos conjuntos regionais.

Fantasia Brasileira no 4 para trombone, piano, bateria e orquestra (1953). No título dessa obra já está anunciada a utilização da bateria. Além disso, há também o grupo de saxofones (dois saxofones altos, dois saxofones tenores, saxofone barítono).

Fantasia Brasileira no 5 para piano e orquestra (1961). Incluem-se na orquestra (flauta, flautim, trompa e cordas completas) dessa obra, dois saxofones altos, dois saxofones tenores e saxofone barítono nos sopros. Na percussão há a bateria e instrumentos de percussão popular brasileira, tais como, tamborim, pandeiro, gonguê, agogô e reco-reco.

Fantasia Brasileira no 6 para piano e orquestra (1963). Na orquestra desta obra (três trompetes, três trombones, tuba, trompa, tímpano, bombo, caixa, prato e cordas completas) há a inclusão de dois saxofones altos, dois saxofones tenores e saxofone barítono nas madeiras e na percussão há um surdo, reco-reco, cabaça, gonguê e pandeiro.

Maria Jesus dos Anjos (cantata umbandista): para coro misto, narrador, orquestra e percussão popular (1964). Nesta cantata para coro (doze vozes masculinas e doze vozes femininas) e orquestra (três trompetes, três trombones, tuba, trompa, três tímpanos, pratos, caixa, bombo, piano e cordas completas) o próprio compositor anuncia no título a utilização de percussão popular. Os instrumentos de percussão populares dessa obra são: triângulo, caixeta, gonguê, cabaça, reco-reco, pandeiro e atabaque.

O negrinho do pastoreio: (bailado) para orquestra (1960), do original para dois pianos de 1958-59. Obra para orquestra (duas flautas, flautim, corno inglês, dois clarinetes, clarinete baixo, dois fagotes, quatro trompas, três trompetes, três trombones, tuba, bells, tímpano, caixa, bombo, harpa, celesta e cordas completas) e na sessão de percussão são incluídos os seguintes instrumentos de percussão popular: pandeiro, reco-reco, tamborim, quatro atabaques e omelê que é um chocalho de metal contendo sementes e pedrinhas. (FRUNGILLO, 2003, p. 231).

Rapsódia para dois pianos e orquestra de jazz (1936), do original Fantasia Brasileira $n^{\circ}$ 1, para dois pianos. A orquestra que acompanha os dois pianos nesta obra 
tem a seguinte formação instrumental: flauta, oboé, clarinete, dois trompetes, dois trombones, violinos, violas, violoncelos, contrabaixos, tuba e tímpano. Dois saxofones altos e dois saxofones tenores são incluídos, além da bateria na percussão. É notável que Radamés Gnattali nomeou este grupo instrumental como "orquestra de jazz", possivelmente pelo uso da bateria e em grande medida pelo emprego dos saxofones aliados aos metais, que por sua vez estão presentes na orquestra sinfônica e também na big band.

Sinfonia Popular no 1 (1956). A orquestra dessa obra tem a seguinte formação: duas flautas, flautim, dois oboés, corno inglês, dois clarinetes, clarinete baixo, dois fagotes, quatro trompas, três trompetes, quatro trombones, tuba, caixa, bombo, pratos, tímpano, harpa e cordas completas. Instrumentos de percussão popular, tais como, chocalho, reco-reco e triângulo, são incluídos na percussão.

Sonatina Coreográfica (quatro movimentos dançantes) para orquestra (1952) do original para piano solo, de 1950. A orquestra é composta por duas flautas, flautim, oboé, corno inglês, clarinete, clarinete baixo, dois fagotes, trompa, três trompetes, dois trombones, bombo, pratos, tímpano e cordas completas. São incluídos um saxofone alto nas madeiras e a bateria na percussão.

Suíte Brasileira (seis danças). Para piano, guitarra elétrica, contrabaixo e bateria, com orquestra (1954), do original "suíte popular brasileira para violão e piano" de 1952. O contato com essa obra traz já em seu título, instrumentos ligados ao jazz, que são, a bateria, a guitarra elétrica e o contrabaixo, que é acústico, porém tocado em pizzicato, ao modo jazzístico. No instrumental da orquestra constam os seguintes instrumentos: flautim, flauta, dois oboés, corno inglês, dois clarinetes, dois clarinetes baixos, trompa, três trompetes, três trombones, tuba, tímpano e cordas completas. Aliados à orquestra há um grupo de cinco saxofones (dois altos, dois tenores e um barítono) que contribuem para a intenção de se obter texturas jazzísticas.

Três miniaturas para orquestra (1940). A orquestra desta obra conta com duas flautas, flautim, dois oboés, dois fagotes, corno inglês, dois clarinetes, clarinete baixo, quatro trompas, três trompetes, quatro trombones, tuba, celesta, harpa, piano, pratos, caixa, bombo, tímpano, triângulo, reco-reco, chocalho e cordas completas.

Impressões da Cidade para piano e orquestra (1948). A orquestra dessa obra é formada por duas flautas, dois oboés, corno inglês, dois clarinetes, clarinete baixo, fagote, duas trompas, três trompetes, dois trombones, caixa, tímpano e cordas completas, com a inclusão de um surdo na percussão, instrumento este que é comum ao samba.

Música para Rádio - para orquestra, oito movimentos (1941). Orquestra formada por flauta, flautim, oboé, dois clarinetes, fagote, três trompetes, dois trombones, bells, harpa e cordas completas. Na percussão, há o toque jazzístico no emprego da bateria. Um violão de acompanhamento, tocado ao modo dos seresteiros, é incluído na orquestração. 
Suíte retratos para piano e orquestra (198?), do original para bandolim e orquestra de cordas de 1956-57. A orquestra formada por flauta, flautim, dois oboés, dois clarinetes, clarinete baixo, dois fagotes, quatro trompas, bells, e cordas completas tem um pandeiro incluído na percussão.

\subsection{Peças para Orquestra de Câmara}

Também se localizam instrumentos de música popular brasileira ou de jazz na música que Gnattali dedicou à orquestra de câmara.

Concertino no 1 para harmônica de boca e orquestra de câmara (1956). A instrumentação deste concertino é formada por duas flautas, flautim, dois oboés, corno inglês, dois clarinetes, clarinete baixo, dois fagotes, trompa, tímpano e cordas completas. O triângulo e a bateria são incluídos na percussão. O instrumento solista, a harmônica de boca, não é comum de se encontrar na música de concerto.

Concertino no 3 para piano (pequenas mãos) e orquestra de câmara (1946). A orquestra de câmara que acompanha o piano nesta obra é formada por flauta, oboé, dois clarinetes, clarinete baixo, fagote, trompa, trompete, caixa, bombo e cordas completas. São incluídos na família da percussão o reco-reco, o triângulo e o gonguê.

Suíte para pequena orquestra (1940). A orquestra de câmara desta peça é formada por duas flautas, dois oboés, dois clarinetes, dois fagotes, duas trompas, dois trompetes, dois trombones, piano, violinos 1, 2 e 3, viola, violoncelo e contrabaixo. Há uma bateria como único instrumento de percussão da suíte.

\subsection{Peças para Orquestra de Cordas}

A orquestra de cordas também foi associada por Gnattali aos instrumentos da música popular brasileira e do jazz:

Brasiliana no 2 (samba em três andamentos) para bateria e piano solistas, orquestra de cordas e percussão popular (195?). Um dos solistas da obra, a bateria, é um instrumento intrínseco ao jazz. A orquestra de cordas (violinos 1, 2, 3 e 4, violas 1 e 2, violoncelos 1 e 2 e contrabaixos) ganha uma sessão de percussão popular formada por dois tamborins, dois chocalhos, surdo, ganzá, cabaça e prato de cozinha.

Canção e dança para harmônica de boca e orquestra de cordas (1959). Três anos após o concertino para harmônica de boca e orquestra, esse mesmo instrumento recebe uma outra peça, desta vez acompanhado por orquestra de cordas (violino 1 e 2, viola, violoncelo e contrabaixo). 
Concertino no 3 para violão solista, com flauta, bateria, bells e orquestra de cordas (1957). A orquestra de cordas (violino 1 e 2, viola, violoncelo e contrabaixo) que acompanha o violão solista desta peça possui, como mencionado no título, flauta, bells e a bateria que é o instrumento popular desta orquestração.

Concerto no 2 para harmônica de boca e orquestra (1968). Esta é a terceira obra que Radamés Gnattali escreve para harmônica de boca e a segunda em que é acompanhada pela orquestra de cordas (violino 1 e 2, viola, violoncelo e contrabaixo).

Concerto para acordeom e orquestra de cordas (1977). Radamés Gnattali escreve esta obra certamente inspirado pelo acordeom presente em regionais que acompanhavam cantores no rádio das décadas de 1930-40. O solista é acompanhado pela orquestra de cordas (violino 1 e 2, viola, violoncelo e contrabaixo) e na percussão conta com duas tamboras, instrumentos assim designados no manuscrito do compositor e por isso mesmo, constam com esse nome em seu catálogo de obras. Não encontrei nenhuma referência a respeito dos instrumentos denominados tamboras. Possivelmente são um tipo de tambor.

Concerto no 2 para trompete, piano, bateria e orquestra de cordas (1952). Nesta obra, outra vez figura a bateria como único instrumento de percussão da orquestração.

Retratos (suíte) para bandolim solista, conjunto de choro e orquestra de cordas (1956 - 57). O conjunto de choro presente na instrumentação desta suíte é composto por cavaquinho, dois violões e pandeiro.

Retratos (suíte) para camerata Carioca e orquestra de cordas (1981), do original para bandolim e orquestra de cordas (1956-57). O grupo de música popular brasileira incluído nesta peça é a Camerata Carioca, formada por bandolim, cavaquinho, dois violões, violão de sete cordas e percussão popular.

Valsa, samba-canção e choro para violino solista, dois violões, pandeiro e orquestra de cordas (1959). A orquestra de cordas (formada por violino 1, 2 e 3, viola, violoncelo e contrabaixo) que acompanha o violino nesta obra tem o apoio harmônico de dois violões. O pandeiro figura como único instrumento de percussão.

\subsection{Música de Câmara}

Radamés Gnattali empregou instrumentos musicais populares também em sua produção camerística. As dificuldades de se amalgamar timbres em pequenas formações, tais como duos, trios, quartetos etc., não quebrantaram o ímpeto experimental do compositor, que igualmente, neste terreno, procurou utilizar instrumentos já consagrados pela música popular brasileira ou norte-americana em sua produção de concerto. Do catálogo do compositor podem-se localizar as seguintes obras: 
Brasiliana no 7 para saxofone tenor e Quinteto Radamés Gnattali (195?). Obra escrita para saxofone solo acompanhado pelo Quinteto Radamés Gnattali, que contém em sua formação, piano, acordeom, guitarra elétrica, contrabaixo e bateria. O quinteto Radamés parece ter a intenção de fundir a sonoridade do jazz, através da guitarra elétrica, contrabaixo, bateria e, em certa medida, do piano, com a sonoridade dos grupos regionais representada pelo acordeom.

Variações sem tema para cavaquinho e piano (1983). Nesta obra, Radamés alia o timbre do piano, instrumento já consagrado no jazz e na música de concerto com o cavaquinho, que é intrínseco ao choro e ao samba.

Fantasia Brasileira no 1, transcrição para sexteto Radamés Gnattali (1985?). O Sexteto é formado por dois pianos, guitarra elétrica, contrabaixo, bateria e acordeom. Tratase do Quinteto Radamés Gnattali com o acréscimo do segundo piano.

Moto contínuo no 1 para Quinteto Radamés Gnattali(1985?). Trata-se de uma versão para o Quinteto Radamés Gnattali do original para piano solo de 1964.

Sonatina Coreográfica para o quinteto Radamés Gnattali (1956?). Trata-se de uma transcrição para o Quinteto Radamés Gnattali, do original para piano solo de 1950.

Uma rosa para Pixinguinha, para o Quinteto Radamés Gnattali (198?). A obra é uma transcrição do original para piano solo de 1964 para o Quinteto Radamés Gnattali.

Alma Brasileira (choro) para Camerata Carioca (198?). Transcrição do original para piano solo (1930) para a Camerata Carioca, que é formada por bandolim, cavaquinho, dois violões, violão de sete cordas e pandeiro. Nesta Transcrição há também o piano.

Concerto para acordeom solista e Camerata Carioca com piano (1980?). Transcrição do original para acordeom e orquestra de cordas, de 1977.

O operário em construção, para canto, narrador e Camerata Carioca com piano (1966). Versão para a Camerata Carioca do original para canto, narrador, piano e percussão de 1966.

Retratos (suíte) para bandolim solista e Camerata Carioca (1979). Trata-se de uma transcrição para Camerata Carioca do original para bandolim e orquestra de cordas de 195657.

Sexteto para Camerata Carioca (1981). Obra para a camerata carioca, tendo o pandeiro substituído pela bateria. Extraída do Concerto para bandolim e orquestra de cordas de 1956-57. Radamés Gnattali, mais uma vez, parece ter como objetivo amalgamar a sonoridade de um regional com a bateria, instrumento este advindo da música norteamericana.

Suíte Brasileira para Camerata Carioca com piano e flauta (198?). Esta peça é uma transcrição da Suíte para pequena orquestra de 1940 para Camerata Carioca com piano e flauta. 


\section{Considerações finais}

Com base na lista por mim apresentada, percebe-se que há um número significativo de peças de concerto de Gnattali nas quais foram empregados instrumentos ligados à música popular brasileira ou ao jazz. São 48 obras com essa característica experimental dentre as 274 músicas de concerto que constam em seu catálogo. Pode-se observar que todas elas foram escritas a partir da década de 1930, data em que Radamés Gnattali dá início à sua carreira de maestro-arranjador como músico contratado da Rádio Transmissora. É neste trabalho que ele estreita sua aproximação com os ritmos da música popular brasileira, com seus instrumentos, com o grupo regional que nesta época já é mão de obra profissional em rádios e gravadoras, tanto como executante de música instrumental como realizadores de acompanhamentos para cantores.

Seu contato com o jazz e com as jazz bands, neste momento se intensifica. É a partir deste período, quando trabalha como arranjador, que Gnattali começa a incluir em sua obra de concerto, não só elementos técnicos e estéticos da música popular brasileira urbana e do jazz, mas também seus instrumentos. Esses fatos corroboram a tese de que a experimentação instrumental de Radamés Gnattali vem da música popular urbana e da sua necessidade profissional de estudar e entender esses instrumentos para que fossem utilizados de maneira adequada nos arranjos para os cantores do rádio e das gravadoras da época. O próprio Radamés admitiu que os arranjos escritos por Galvão na Rádio Transmissora, despertaram seu interesse para utilizar esses instrumentos, pois essas sonoridades instrumentais o encantavam, bem como as texturas conseguidas nos grupos de música popular, levando-o a experimentar esse novo leque de possibilidades sonoras também em sua obra de concerto. Foi sua função de arranjador que lhe trouxe a prática de escrita que - levou à ampliação da sua capacidade de compor, estimulando sua criatividade e seu

imaginário de criador. É importante salientar que grande parte das obras elencadas nesse artigo ainda não foram editadas ou digitalizadas e se encontram em manuscritos originais que estão em poder da família Gnattali. A maioria delas também nunca foi gravada.

Por fim, espero ter demonstrado, com esse artigo, a forte influência exercida pelo repertório e pelos instrumentos oriundos da música popular urbana na música de concerto de Radamés Gnattali. Esse tipo de prática era evitado na época, pelos compositores da escola nacionalista, logo, parece-me inequívoco relatar que Gnattali inaugurou uma nova escrita na música de concerto brasileira.

\section{Referências}

ANDRADE, Mário de. Ensaio sobre a música brasileira. São Paulo: Livraria Martins Ed., 1962. 
BARBOSA, Valdinha; DEVOS, Anne Marie. Radamés Gnattali; o eterno experimentador. Rio de Janeiro: Funarte; Instituto Nacional de Música, 1984.

CANDÉ, Roland de. História universal da música. São Paulo: Martins Fontes, 1994. 2 v. Tradução: Eduardo Brandão. Revisão da tradução: Marina Appenzeller.

COMPOSITORES de América: datos biográficos y catálogos de sus obras. Washington: Secretaria General - Organizacion de los Estados Americanos, 1970. v. 16.

CORREA, Marcio Guedes. Concerto Carioca no 1 de Radamés Gnattali: a utilização da guitarra elétrica como solista. Dissertação de mestrado apresentada ao Instituto de Artes da Unesp, 2007.

DIDIER, Aluisio. Radamés Gnattali. Rio de Janeiro: Brasiliana Produções, 1996.

DINIZ, André. Almanaque do choro. Rio de Janeiro: Jorge Zahar Ed.,2003.

FRUNGILLO, Mário D. Dicionário de percussão. São Paulo: Editora Unesp; Imprensa Oficial do Estado, 2003.

LOWELL, Dick; PULLIG, Ken. Arranging for large jazz ensemble. Boston: Berklee Press, 2003.

SQUEFF, Enio; WISNICK, José Miguel. O nacional e o popular na cultura brasileira: música. São Paulo: Brasiliense, 1982.

TRAVASSOS, Elizabeth. Tradição oral e história. Revista de História, São Paulo, n. 157, segundo semestre 2007. Departamento de História da USP.

TINHORÃO, José Ramos. História social da música popular brasileira. São Paulo: Editora 34, 1998.

TINHORÃO, José Ramos. Pequena história da música popular. São Paulo: Círculo do Livro, [197-?]. Licença editorial por cortesia da Editora Vozes. 